\title{
Bream, Birtwistle, and Beyond: The Genesis of a New Work
}

\author{
Jonathan Leathwood | England \\ University of Denver | United States of America
}

\begin{abstract}
Resumo: Nestas memórias pessoais, o autor descreve sua colaboração de cinco anos com Julian Bream, durante a fundação do Julian Bream Trust. Ele mapeia a gênese da obra Beyond the White Hand, de Harrison Birtwistle, e descreve encontros com Bream e Birtwistle para discutir possíveis revisões da escrita para violão. Seçốes adicionais descrevem a abordagem de Bream ao trabalhar com compositores, ao montar programas de concerto e sua abordagem no que diz respeito à interpretação em geral.
\end{abstract}

Palavras-chave: colaboração compositor-intérprete, Julian Bream, Harrison Birtwistle, Picasso e o violão, repertório contemporâneo para violão.

\begin{abstract}
In this personal memoir, the author describes his five-year association with Julian Bream during the founding of the Julian Bream Trust. He charts the genesis of Harrison Birtwistle's work Beyond the White Hand and describes meetings with Bream and Birtwistle to discuss potential revisions to the guitar writing. Additional sections describe Bream's approach to working with composers, building concert programs, and his approach to interpretation in general.
\end{abstract}

Keywords: composer-performer collaboration, Julian Bream, Harrison Birtwistle, Picasso and the guitar, modern guitar repertoire. 
"often make bad suggestions_-but I know when I have." It is the evening of July 1, 2013. Julian
Bream is opening a bottle of his favorite red burgundy and summing up the meeting that has
just ended.

Harrison Birtwistle has just left. The three of us, watched by Django, Julian's unignorable black Labrador, have been working through Birtwistle's new piece, Beyond the White Hand: Construction with Guitar Player, experimenting with ways to make it as compelling as possible on the guitar.

Corrections, changes, enrichments—none of these is easy when it comes to music as individual as that of Harrison Birtwistle. His is a rough-edged sound world with its admirers and (in the guitar world especially) its detractors. What was known in the fifties as the Manchester School of new music-Harrison Birtwistle, Peter Maxwell Davies, Alexander Goehr, John Ogdon, and Elgar Howarth — had already produced a divisive Bream commission: Davies's Hill Runes, a resplendently dissonant and contrapuntal work that bypasses the landscapes of Spain for the lunar vistas of the Orkneys. I don't know if Beyond the White Hand is more uncompromising than Hill Runes, but it is equally idiosyncratic and far longer, and we were attempting to understand it almost in real time.

On receiving the score a month or so before the meeting, I wondered what would happen to Birtwistle's music as it passed through the sensibilities of Julian Bream, arch-communicator and archinterventionist. Ever since he began to commission new works in the 1950s, Bream had done far more than resolve unplayable chords. He personalized each one with effects, colors, fingerings, and voicings that seem to blend into the texture of the composer's music like a watermark. Later in this essay I will come back to our July meeting and illustrate some of the suggestions that were made-the bad and the good. But first, I should explain how I came to be there and what I had already learned about Julian and his approach to collaboration.

\section{I}

Julian Bream gave his last public concert in 2002, though he continued to perform in occasional private events. Within a few years he had sold his Wiltshire property, moved to a small bungalow, and redistributed his art collection; now he began to consider what he might do in retirement to add to his legacy. The plan he formed was threefold. First, he would write his memoirs; second, he would support young guitarists in their studies by offering scholarships and personal mentoring; and third, he would commission a new series of substantial works from non-guitarist composers. These latter 
two projects led him to form the Julian Bream Trust, which continues today under the stewardship of John Williams.

My involvement began in 2008, when I received a letter, rather out of the blue, from Julian. Would I be interested, he wanted to know, in helping him with the commissioning of new music, working with the composers and performing the premieres? Thus it was that I came to visit Julian in his home two or three times a year until November 2013, shortly before the Birtwistle premiere, when I had to withdraw from the project because of injury. The superb Andrey Lebedev took over the task and performed Beyond the White Hand in December of the following year.

Writing was part of Julian's daily routine at that time, and one of the pleasures of those visits was reading samples of his work. Some years before, with the help of a coauthor, he had begun and then abandoned a conventional autobiography: he felt that it lacked authenticity. Now he was trying again on his own and with a much more personal approach: a series of autobiographical essays, each illuminating a facet of his life as a musician. The topic could be a piece of music, an event, a person, or a place. Each time I visited, he would serve tea, hand me a newly finished chapter in typescript, and then discreetly withdraw for a quarter of an hour. The topics included an impromptu performance of the Chaconne in a London pub; playing Berkeley's Sonatina to Segovia on the maestro's Hauser; there was even an essay on halls-in particular, Wigmore Hall and Segovia's abandonment of it in favor of the much larger Royal Festival Hall.

The last chapter I saw completed was about the bass arioso "Betrachte meine Seel” in Bach's St. John Passion. Julian had played the lute obbligato, and he had become fascinated by Bach's instrumentation: lute, two violas d'amore, organ, and harpsichord. In his essay, he invoked the Islamic origins of the lute and the viola d'amore to explain Bach's unusual scoring: the ensemble created a strange and exotic vessel for the poem, which meditates on how the thorns that pierce Christ's flesh make possible the flowers that bloom in the soul of the redeemed sinner. Playing in Bach's Passion, Julian told me, had nourished a gradual awakening of faith in his life. If I recall correctly, that personal testament of faith was stated not so much in the essay as in Julian's spoken words after I had read it. But it was real: on that same visit I noticed an old book by Victor Gollancz: Man and God: Passages Chosen and Arranged to Express a Mood about God and Man (1951). Opening it, I found an anthology of passages from a multitude of ages and cultures. "I take it in my car," Julian said, "and I read it at the traffic lights.” 
Eventually, Julian's writing was disrupted again. The memoir remains incomplete, buried in mountains of papers, many handwritten. These are in the hands of his executors, but perhaps one day we will see something in print.

Julian was, by the way, critical of Segovia's decision to abandon Wigmore Hall. He considered it the ideal venue for Segovia's sound and indeed, his own sound. It was in Wigmore Hall, then, on November 21, 2011-the anniversary of Julian's own Wigmore debut - that I played a concert to launch the Julian Bream Trust, with a program of Julian's own choosing. There were not yet any new commissions to perform, but Julian wanted to lay down a marker for future events with a serious, substantial program. Two of his requests, the twelve Villa-Lobos Studies and Bach's 6th Cello Suite, were works long associated with him, but for the rest of the program, he asked me to play two works he had never performed but wanted to hear. The first was Petrassi's Nunc: he had once heard it played by John Williams and thought it the best performance he had ever heard from his admired friend. The other work was Nicholas Maw's Music of Memory, which Julian called quite the finest guitar work of recent years, allowing only that the fugal variation might have benefited from additional experimentation and editing.

The next concert was to contain the premieres of the Julian Bream Trust's first two commissions: Birtwistle's Beyond the White Hand and Brouwer's Sonata no. 5, Ars Combinatoria. To accompany them, Julian chose Bach’s Suite BWV 996, the José Sonata, a triptych of Roussel, Falla, and Gerhard, and another work that he had just discovered: Lindberg's Mano a Mano. Although I did not perform this concert, I mention it to underscore just how uncompromising Julian's programming was: in one letter to me, he mused about bringing back the three-part concerts of the mid-twentieth century. As for this program, I suggested that a hundred minutes of music (not counting breaks) might test the modern concertgoer's stamina-of course, I was thinking partly of myself. His sublimely unprintable two-word response made it clear that the modern concertgoer's stamina was not his first priority.

\section{II}

Harrison Birtwistle's new guitar piece began life decades earlier as a rumor, floated in A Life on the Road, Tony Palmer's account of a year following Bream on tour. This was in 1981- why, then, did it take over thirty years for anything to emerge? In the book, Palmer reports a conversation 
between Bream and Peter Maxwell Davies, following the premiere of Hill Runes. Apparently unaware of the reception his own piece would receive, Davies tells Bream he is brave to ask Birtwistle to write something. Bream replies that the project seems to have stalled: Birtwistle is bored with the guitar's limitations, especially its lack of a separate low register that can be called on at special moments:

\footnotetext{
"I'm fond of Harry, and I think he has something personal and original to say in his music. I rang him up the other day to ask him what sort of piece he had in mind. He didn't say much except to say that he was bored and felt a bit constricted by the low E string on the guitar. So I suggested he think of it as D double sharp, then he'd have a whole new ball game at his disposal." (PALMER, 1982, p. 95)
}

Around 1997 I had a chance to ask Birtwistle about the piece myself. I was teaching at King's College London, where he held a chair as professor of composition. His rare visits were big occasions, and one afternoon, I was invited to join him and a couple of colleagues in the pub. At King's, he generally worked only with select graduate composers, but on that day he had just taught a class to some second-year undergraduates: "I asked them what was their favorite second-rate piece of music," he said gleefully-Birtwistle the disruptor.

"What's yours?” I asked.

“Bolero."

I asked him about the status of the guitar piece, and he dismissed any suggestion that he was unwilling to write it. "If Julian pays me my commission fee, I'll write him his piece.” Apparently, then, the commission was never quite formally made, but there was more to it than business. Julian told me that when the subject came up as both were becoming famous, Birtwistle said, "Look, Julian. If you want a piece that you can play in your concerts and make an effect, go and ask another composer. Don't ask me. That's not what I do.”

\section{III}

Certainly Julian, like Segovia, always thought of the pieces that were written for him in terms of the live act. Not that he avoided challenging the audience with unfamiliar sounds-that is part of his enduring legacy. He even told me that he was devoting part of his retirement to commissioning new music for the guitar because young players were not doing enough "of interest." But although he had no wish to make difficult music easier, he shared Hans Keller's view that a performance 
completes the composition, and at times he behaved like a composer manqué, trusting his own instincts over the composer's wishes.

When I played for the seventy-year-old Richard Rodney Bennett, I asked him what it was like to work with Julian Bream. "I was afraid of him," was Bennett's response. He explained that when they worked together, Bream was the more celebrated of the two, a household name where Bennett was not. When Bennett wrote his guitar concerto, Bream thought of adding a flurry of sweeping arpeggios at the end of the cadenza. "I said no. But he did it anyway." The extra arpeggios can be heard on Bream's recording.

Mostly, though, composers went along. I asked Julian what was the most challenging work he had ever commissioned, and he named Michael Tippett's Blue Guitar. "I gave the first performance in America and wasn't sure about the effect. So, on the second performance I omitted some passages [from the movement 'Juggling'] and reordered the movements. Then I called Michael and told him what I had done.”

"What on earth did he say?"

"He said, 'How did it sound?"

It seems that Bream never lacked that confidence to tell a composer what he thought and to make snap judgments that other, more deferential musicians would hesitate to make. Take Roberto Gerhard, who approached Bream with a solo guitar piece in the mid-fifties. Gerhard was close to sixty years old, a Catalonian exile living in Cambridge and a major figure in British musical life at the time. Bream was thirty-seven years his junior. This is how Julian recalled the experience to me: "He brought me his piece, and it was all strumming. I told him, 'I can't play this in my concerts.' He wasn't happy with that, and he took the piece away.”

I remember my pious shock when he told me this, thinking that an entire work-surely a misjudged masterpiece! - by Gerhard had been lost to posterity. Later I realized that this could only have been an early version of the famous Fantasia (1957) and that the rejected manuscript is preserved in the Gerhard archive in Cambridge. It certainly consists of far more than strumming - it is instantly identifiable as a draft of the piece that Bream would premiere and then champion throughout his life. But there are some moments where Gerhard deploys Spanish idioms so literally that evocation seems to fall into distracting quotation. In figure 1 , it is the passage starting in measure 63, with its sliding A-major chord shape, that must have repelled Bream. 
FIGURE 1 - Roberto Gerhard, Fantasia (1957), unpublished manuscript, mm. 58-82.

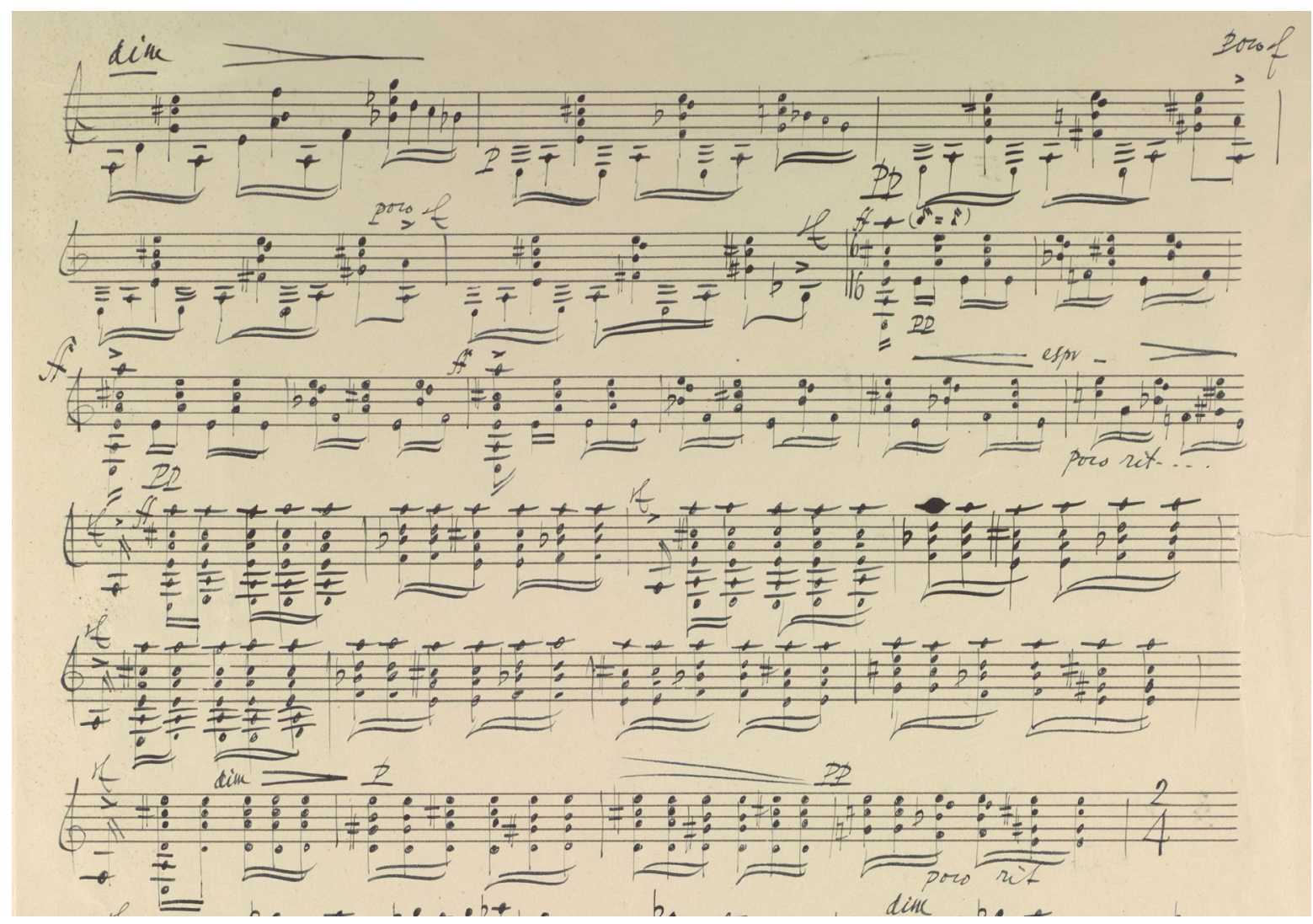

In the final version of the Fantasia, Gerhard weaves a complex web of false relations between different collections_-diatonic, acoustic, octatonic, chromatic. All that remains of the sliding chord is the aphoristic ending, when suddenly we seem to realize how deeply, covertly Spanish the whole piece has been (figure 2). Indirectly, it is Bream we must thank for such finesse.

FIGURE 2 - Roberto Gerhard, Fantasia (1957), published version, mm. 111 to the end.
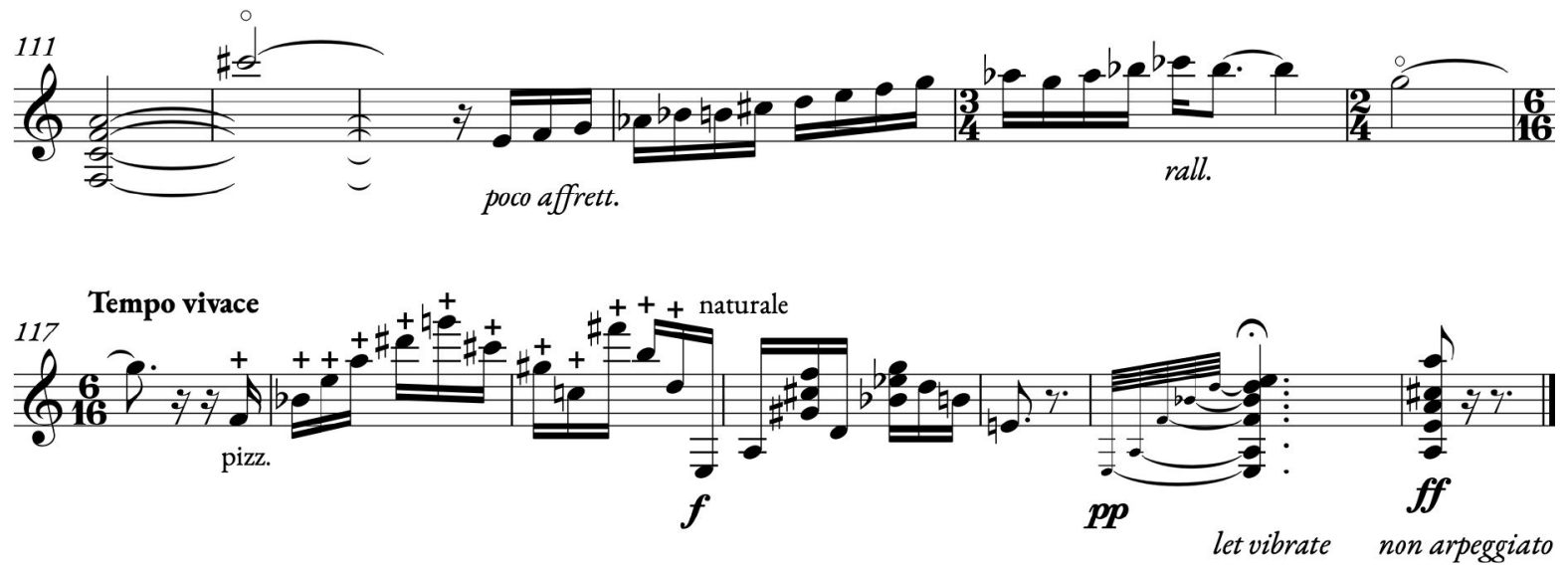


\section{IV}

Birtwistle's piece, when it finally came, proved at fifteen minutes of music to be one of the longest through-composed pieces in the guitar repertoire-episodic, yes, but fluid and tightly woven. It disconcerted Julian. He called me and told me he was expecting something more energetic. The piece, he said, seemed "very sad," and he speculated that it was colored by Birtwistle's grief over the recent loss of his wife. He asked me if I knew Birtwistle's clock pieces for piano (Harrison's Clocks). What if I transcribed some passages from them for possible insertion? (I could not imagine how to begin such a task.) But I think that Julian was focusing mostly on the slow, enigmatic opening episodes of the guitar piece. The central episodes have the energy and punch of any Birtwistle work; certainly, Julian never repeated his doubts.

Birtwistle's manuscript was more or less playable as it stood. The most mysterious thing was the title, neatly inscribed in block capitals: BEHOND THE WHITE HAND. Behond? Was this a Mallarmé-like play of sounds-beyond and bebold_or a mistake? And how to bring it up without appearing unsophisticated? But Harry told me on the phone it was just a mistake: beyond. By then, Julian had become used to behond and was rather inclined to defend it. In the end, the word remains available for other composers to use...

Both the title, Beyond the White Hand, and the subtitle, Construction with Guitar Player, derive from Picasso. Birtwistle has often spoken of how artists such as Klee, Cézanne, Zurburán, and others have stimulated his musical ideas. Challenged with composing for the guitar, he found a natural starting point in Picasso, in whose work the guitar is an essential topic-a site for experimentation. There was some serendipity here: in 2011, the Museum of Modern Art in Manhattan had devoted an entire exhibit to over seventy of Picasso's works with guitar, all from 1912 to 1914. MoMA had produced an accompanying book, written by the exhibit's curator, Anne Umland (2011). Soon after the book was published, I noticed it on Julian's coffee table. It was a gift from the guitarist Forbes Henderson, who had given a copy to Harry as well.

At least three images influenced Birtwistle's compositional process at different times. In 2007, he had composed a miniature for guitar called Guitar and White Hand, after Picasso's 1927 painting, Guitare à la main blanche (figure 3). Written for his son Silas and masterfully recorded by Forbes 
Henderson (2011), it remains unpublished. But it is incorporated into Construction with Guitar Player, both at the beginning (the opening sonority) and then at the end, where it is played in full.

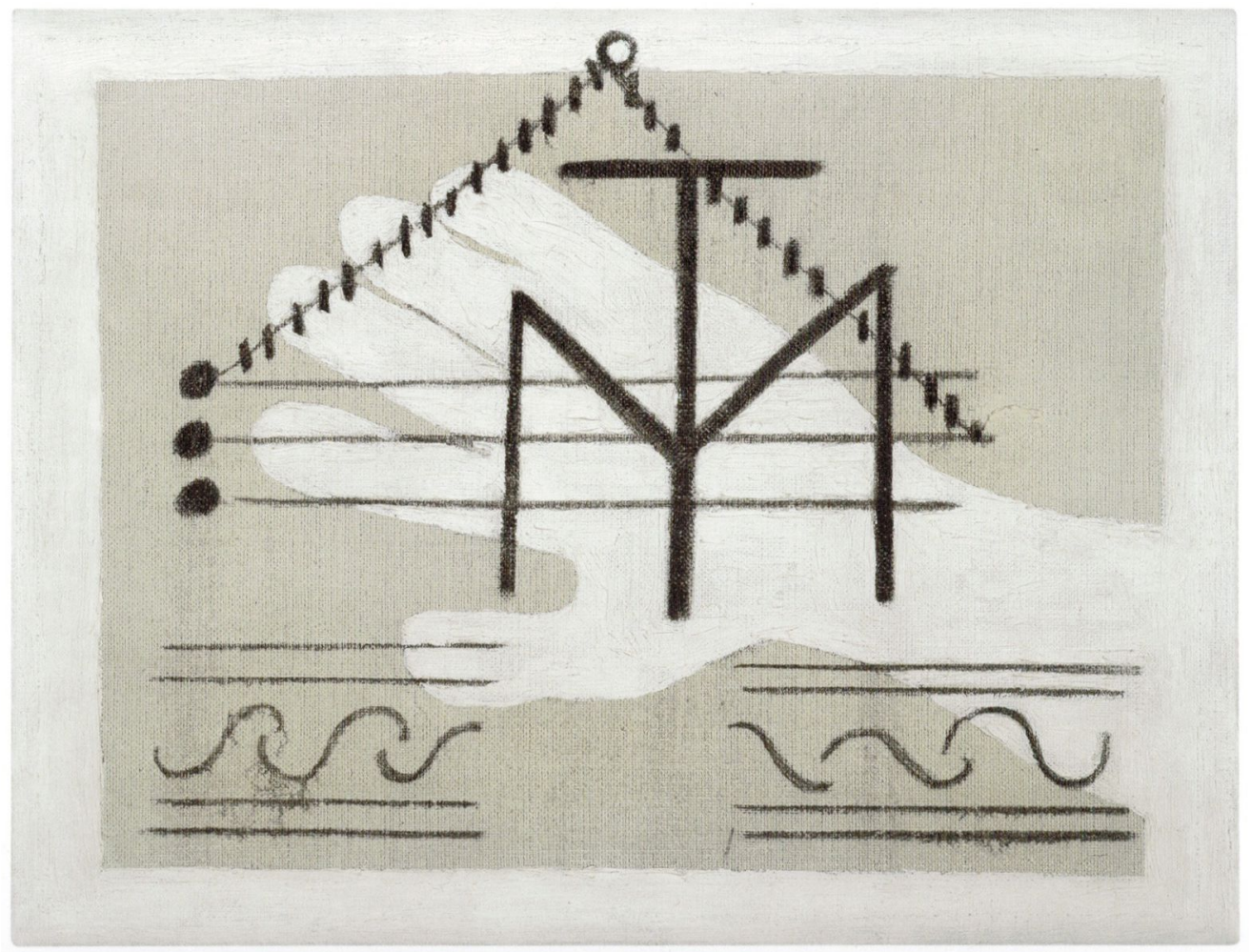

The other two images came from Umland's book. Initially, Birtwistle was fascinated by a page from Picasso's 1912 sketchbook, in which a guitar is mapped into sections. On each section Picasso has added a label from a palette of colors: pink, blue, ochre, white, gray/green, and black. The sketch was never realized in color, although it inspired a reworking (releitura) by my friend, the Brazilian artist Selma Antunes (figure 4). Picasso's sketch suggested to Birtwistle a sequence of short guitar pieces, each devoted to a different color from the palette. The "white" movement was already composed, in the form of Guitar and White Hand. But soon the sketches began to connect into a single whole. The multi-movement plan was abandoned while the contrasting characters remained. 
FIGURE 4 - Selma Antunes, Releitura: Pablo Picasso (2013).

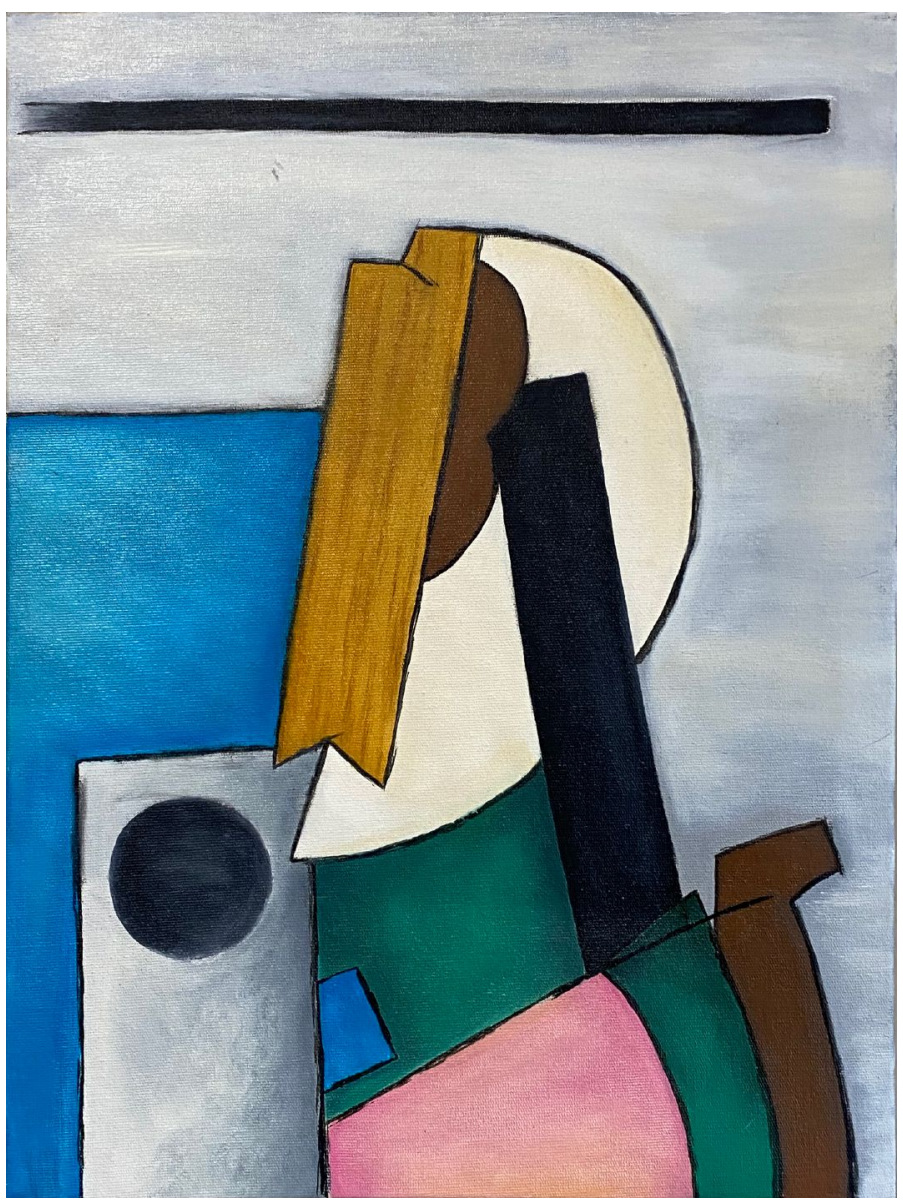

A third stimulus was Construction with Guitar Player (figure 5), an installation arranged and photographed by Picasso in his studio in 1913, a hundred years prior to Birtwistle's own "construction." Picasso's photograph shows a partially drawn and partially painted figure, to which he has fixed arms of newspaper that fold out of the wall, escaping the flatland of the surface of the paper to embrace a real guitar. Everything we encounter in three-dimensional space is a found object: the inexpensive guitar and a table with a wine bottle and other still-life elements. The photograph itself is cut into a fanciful shape, dragging us back to two-dimensionality. 
FIGURE 5 - Pablo Picasso, Construction with Guitar Player (1913).

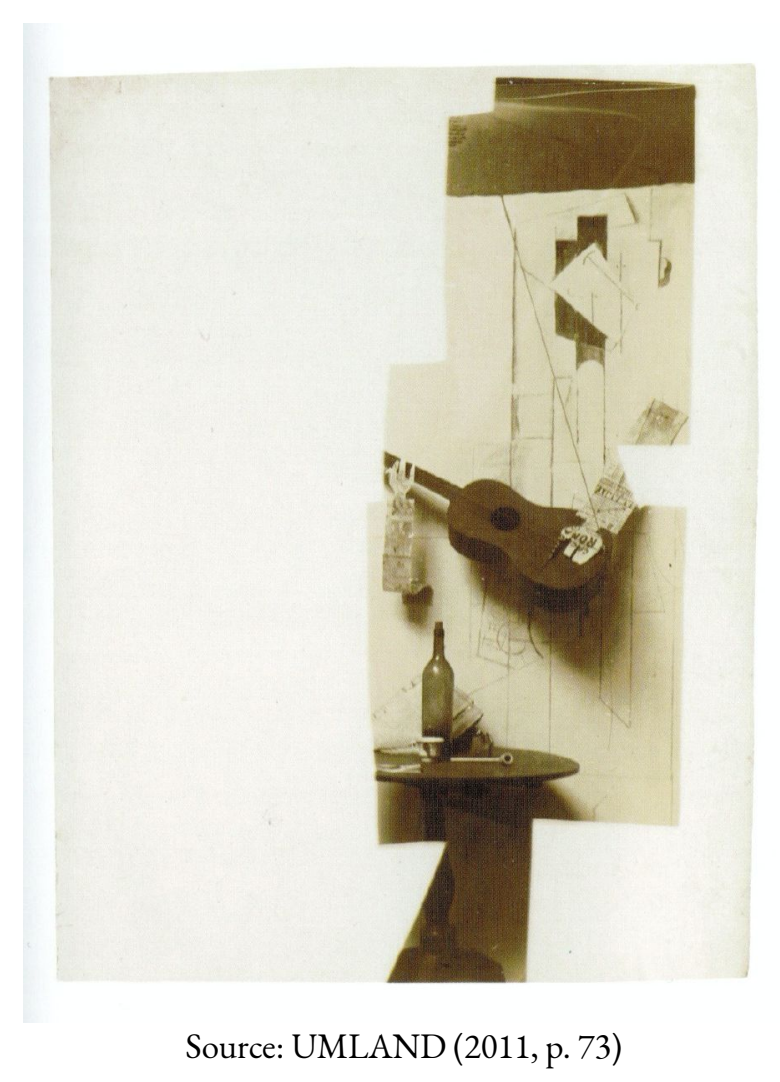

This interplay of dimensions, materials, and realities offers many fruitful parallels with Beyond the White Hand. Navigating its various episodes, we hear pauses, transitions, interruptions, echoes, loops, cross-cutting, digressions-a gamut of connections that Birtwistle conceived in response to Picasso's cropped and contradictory spaces. The episodes (unordered in the initial sketches) teem with independent life: open-ended melodies, hockets, shifting ostinatos, and infectious rhythms that limp unexpectedly. The White Hand music remains at the beginning and the end, and its hollow sonorities are explored and developed throughout.

These sonorities start from the open strings, sounding kaleidoscopic combinations of perfect fourths, perfect fifths, and tritones. As I acquainted myself with the manuscript of Beyond the White Hand, I used improvisation to convert its sonorities into tacit, tactile knowledge. I started with the fifths. One perfect fifth, paired with each of its disjunct transpositions, yields five unique tetrachord classes. Figure 6 presents these tetrachords and a single instance of their use, but they are explored throughout the work, often via signature voice-leading moves like the one found in the first measure. (Note that in all excerpts from Beyond the White Hand, accidentals apply only to a single note.) 
FIGURE 6 - (a) Tetrachords generated by transpositional combination of interval class 5;

(b) examples of their use in Birtwistle, Beyond the White Hand.

a)

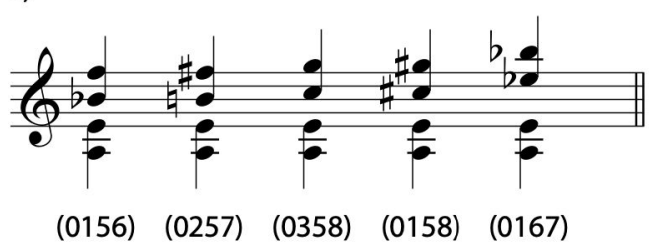

b)
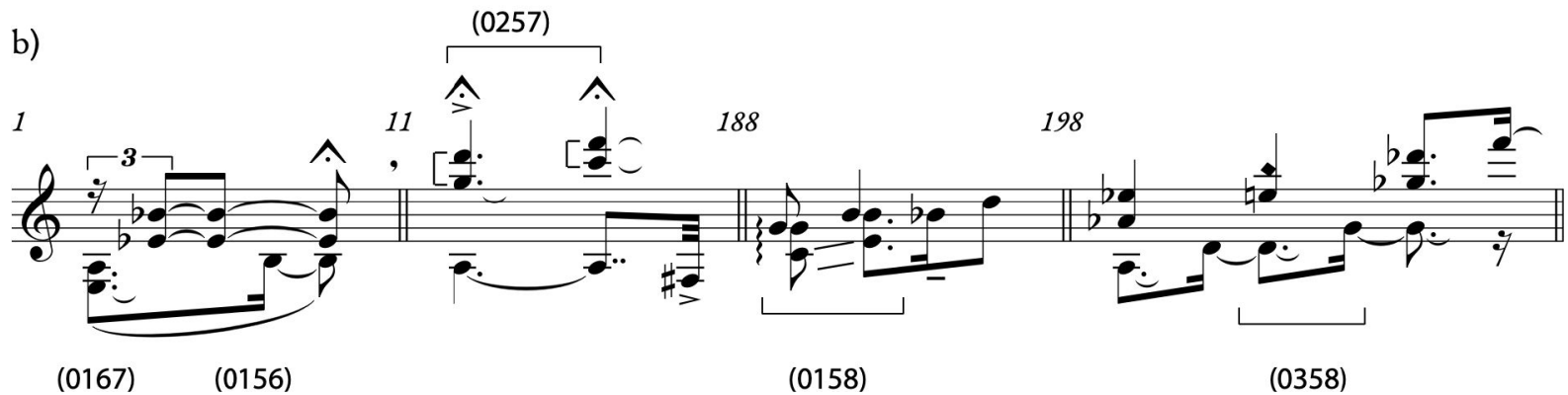

Yet all this is at the service of the ritualistic, pagan quality that keeps one hooked on Birtwistle's music. It is not for nothing that he reached compositional maturity in that period of British culture that produced the genre of folk horror; his looping constructions reach back to cubism but forward to the "hauntology" of British folk, with its samples, its loops, and its fascination with the sonic material of post-war British culture. For this piece to succeed on the guitar, the player must find a very particular aggression. As I worked, I thought of Bream's London masterclasses. If sometimes a student "hit" the guitar—with an unfocused strum, say_Bream would interrupt and say, "That's not pretty is it?" And then he would demonstrate how the guitar could be made to sound both brash and sophisticated at the same time, the basses on his lightly strung guitar buzzing and fizzing.

It is July 1 . Before the meeting with Julian, I am scheduled to meet Harry at his house to play through Beyond the White Hand and discuss possible revisions. "I want help making it more like itself," he tells me on the phone beforehand.

It soon becomes clear that this help is not about close control of detail. Harry no longer has a score of the piece to refer to, having sent the manuscript to his publisher. Right away, I play him the beginning of the piece and ask him whether he wants the open strings to ring on (see the first measure 
in figure $6 \mathrm{~b}$ above: the l.v. tie to the low $\mathrm{E}$ is my addition, and it is how I played it to Harry). The resonances sound ear-tingling, but is this what he wants?

Long pause.

"I'll leave that kind of thing to you," he finally says. "What I want is ideas to make the music more idiomatic on the guitar.”

In another passage, I deliver a suggestion from Julian, emailed to me via the secretary of his Trust. In the measure with harmonics preceding the fast central section (figure 7, line a), what about doubling the harmonics two octaves below, creating a ghostly effect (line b)? Harry isn't sure, so I suggest a heterophonic line of augmented and diminished octaves. I improvise something to give him an idea, switching to other intervals at the cadence (line c).

FIGURE 7 - Birtwistle, Beyond the White Hand, m. 38: (a) manuscript; (b) with added octaves and a half-pizzicato effect, as suggested by Julian Bream; (c) with additions played for Birtwistle by the author.

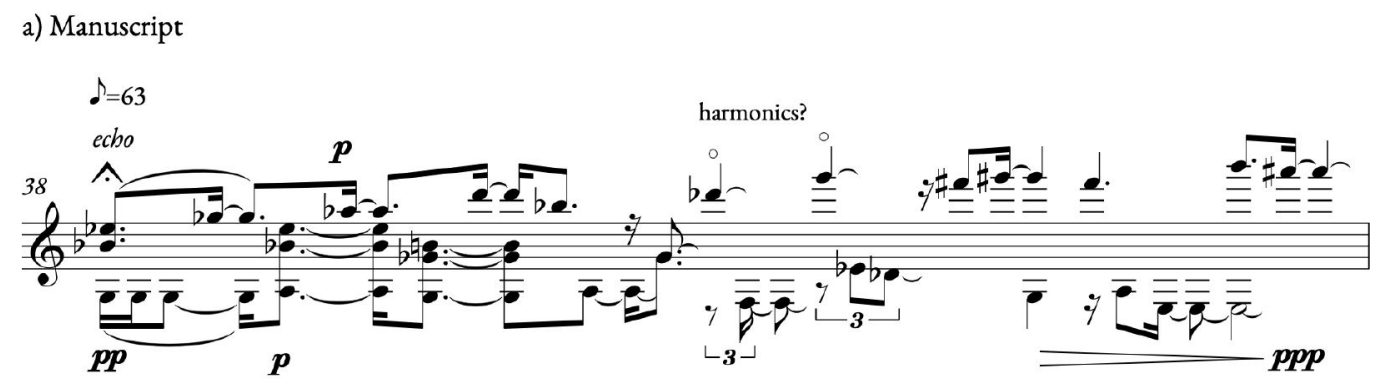

b) With added octaves and a half-pizzicato effect, as suggested by Julian Bream

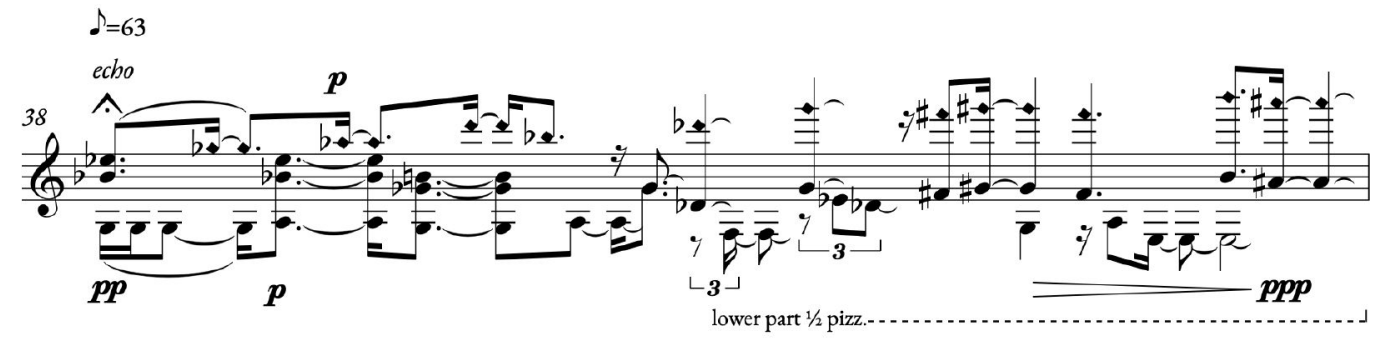

c) With additions played for Birtwistle by the author

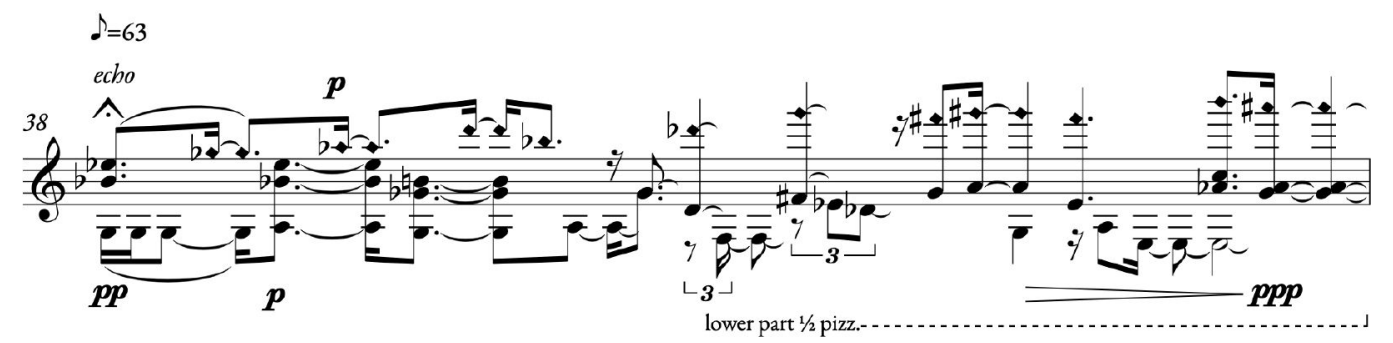


"Yes, that's fine. Write it down.” I pencil it into the score and show it to him, expecting him to refine it, but he simply nods and signals to move on.

Conscious of Julian's concerns, I bring up the role of lively music in the piece. I tell Harry how much I love the most climactic of the piece's various ostinato passages. Can it go on for longer?

"Oh yes, you can have more of that... You can have it by the yard."

In many places, we discuss the idea of adding high harmonics to subtly enhance the texture. The piece cleaves to the low register for the most part, and Harry is concerned about this. In figure 8, the high A harmonics are something improvised in the meeting, played gently enough to blend with the low As, and Harry gives it his blessing.

FIGURE 8 - Birtwistle, Beyond the White Hand, m. 20: diamond-headed harmonics played for Birtwistle by the author.

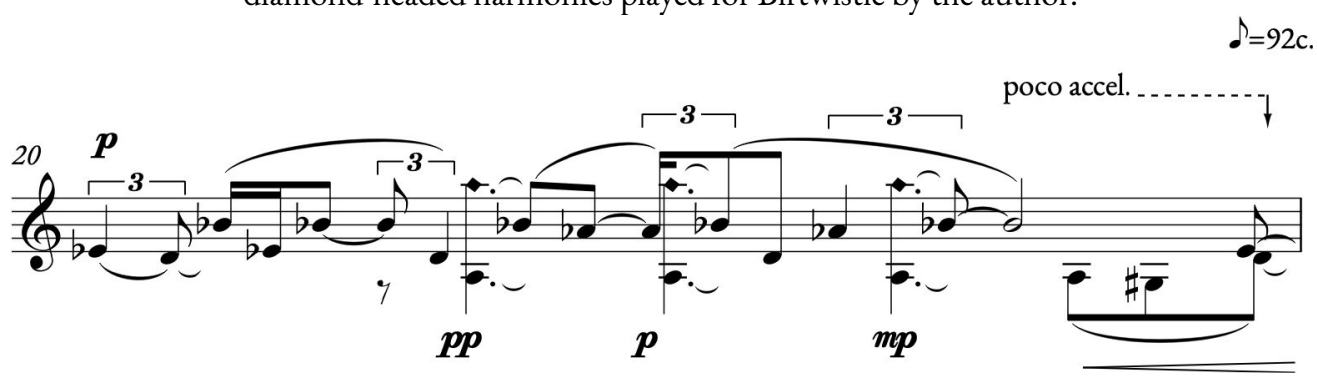

The possibility of enriching the lower registers with harmonics arises again in one of the last ostinato episodes, where a quietly burbling texture is punctured by climactic fifths and fourths (figure 9a). These dyads must explode, but placed as they are in the middle register, it is not easy to generate sufficient power. I suggest "orchestrating” the perfect intervals by adding high harmonics. I improvise the music in figure 9b, and Harry is intrigued: "They sound like complex overtones." He asks me to go away and write it out, and I do, but within a few days I find I can produce a more explosive effect by adding unisons (figure 9c). 
FIGURE 9 - Birtwistle, Beyond the White Hand, mm. 179-80:

(a) manuscript; (b) with added harmonics, as improvised for Birtwistle by the author;

(c) with unisons added by the author.

a) Manuscript
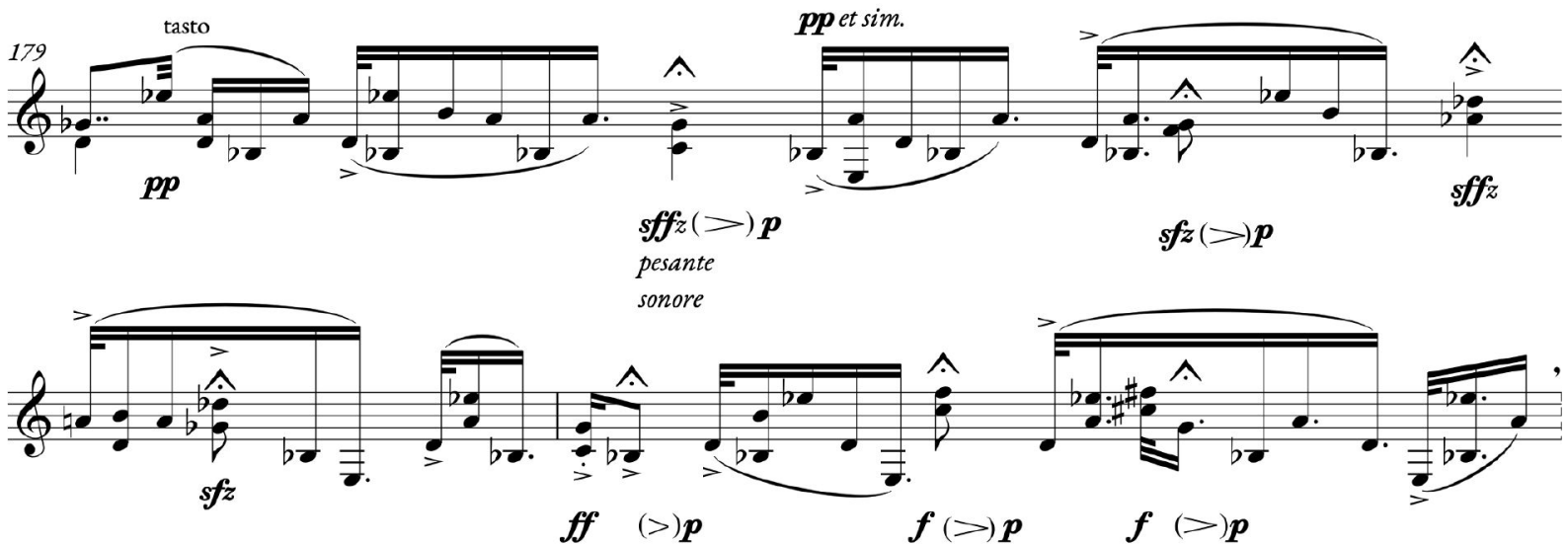

b) With added harmonics, as improvised for Birtwistle by the author
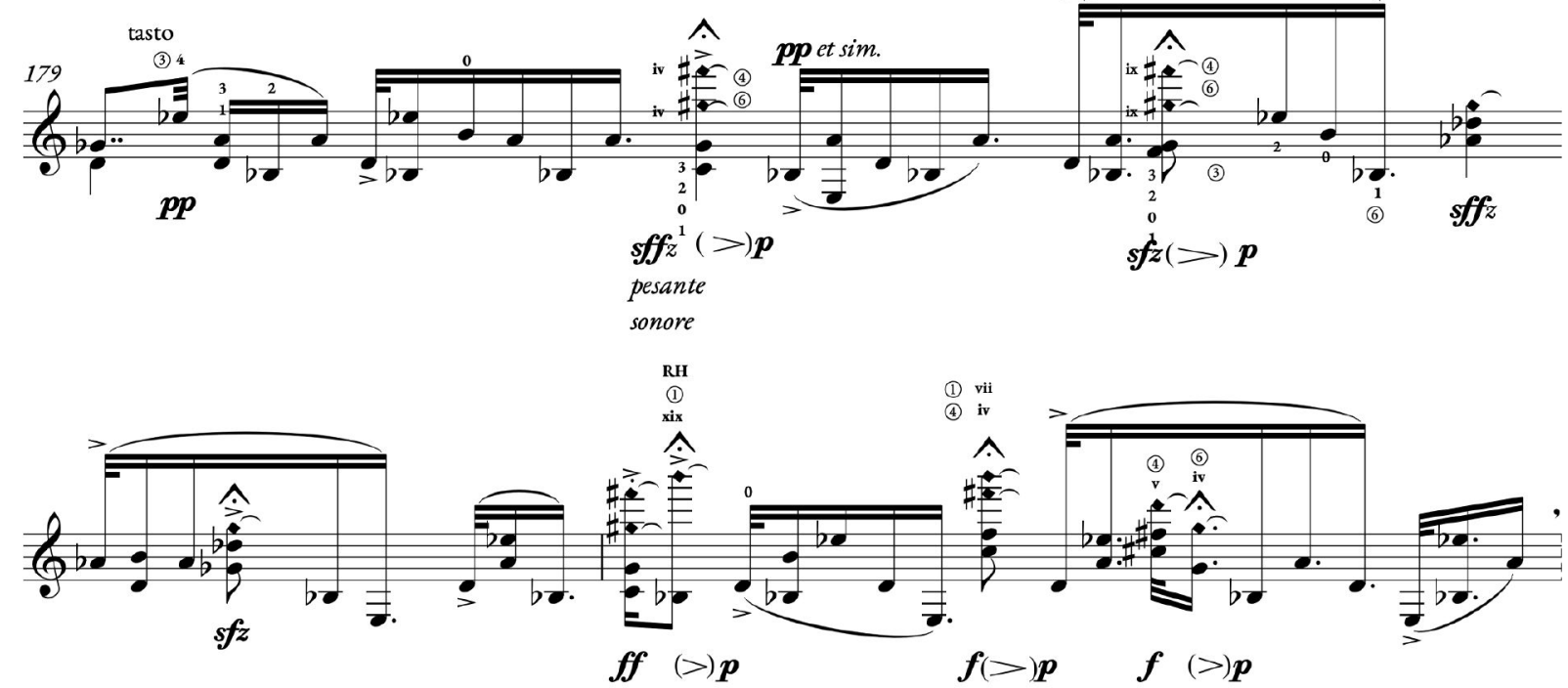

c) With unisons added by the author

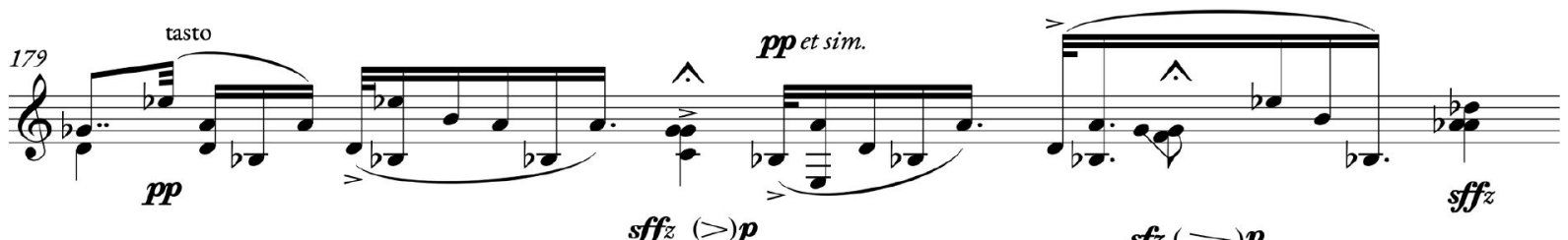

$s f f(\rightarrow) p$

$s f(\supset) p$

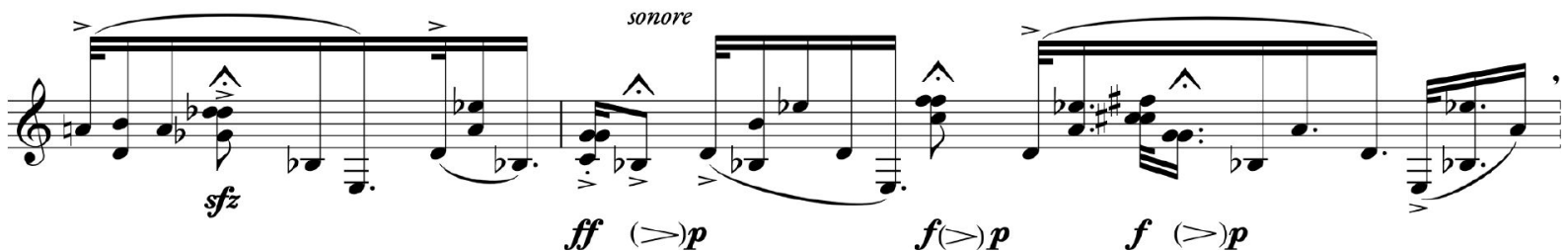


In the manuscript, towards the end, one of the voices features wide intervals that if played literally, convey a hyperexpressive affect. Harry agrees that this is not what he intended, and he approves making some of the high notes into harmonics, so that they can fit into the texture without shifting the left hand up and down (figure 10).

FIGURE 10 - Birtwistle, Beyond the White Hand, m. 185: diamond-headed harmonics played for Birtwistle by the author.

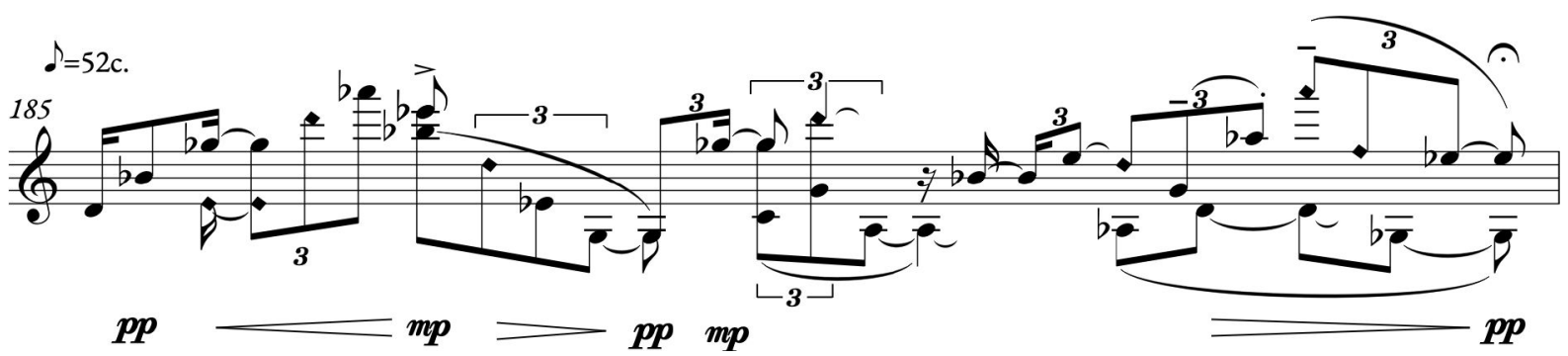

I ask Harry about the tempo relations in the piece-they are complex and on the manuscript the mathematics does not always work out: the character of each episode is always clear, so I suspect they are guides. "I'm writing a piano concerto at the moment," he says, "and for some reason I'm having difficulty hearing the tempi." It's clear that when he composes, he thinks constantly of the pacing.

\section{VI}

"Julian couldn't join us," Harry tells me, with his love of paradoxical remarks, "because his dog is black.” This is never quite explained, but I believe it has something to do with Julian not wanting to take Django out in the sun. At any rate, we go to Julian's house to go through the process again.

Before we start, Julian and Harry discuss the non-classical music they enjoy. Harry is a lifelong devotee of Roy Orbison, the American singer-songwriter, but Julian cannot bring him to mind.

"Oh, you've definitely heard his music, Julian," says Harry, and he sings: "Pretty woman, walking down the street; pretty woman, the kind I'd like to meet... You must know that one.”

"It doesn't ring a bell. I used to like Lonnie Donegan..."

Eventually we get to Beyond the White Hand. Julian sits in his favorite chair with a score on which he has marked his suggestions in advance. He doesn't have a guitar. Harry is on the sofa, just listening - he has forgotten his reading glasses. I complete the triangle sitting with my guitar and 
playing for them. Julian's suggestions come thick and fast—-some for Harry, some for me.

We come to measure 11 (figure 11a). "Now in this chord, Jonathan, add an A and an E," Julian says, without explaining why. There are a number of suggestions like this; I'm reminded of Julian's London masterclasses in the 1990s and how often his instructions to students would come from a place of implicit knowledge-like this, not like that, that's not pretty, don't just hit the guitar, listen to me play it... But suddenly Birtwistle's sparse sonority sounds like something out of William Walton (figure 11b).

Harry protests: "Julian, if you'll just tell me what problem you are trying to solve, then we can try to solve it.”

But there is a problem to be solved. The widely spaced sonorities sometimes fail to make their intended point because one of the layers dies too quickly. And in this passage Julian's next suggestion is an important improvement-double the low A (figure 11c). Adding unisons is a trademark enhancement of Julian's-think of the resonant beginning of The Blue Guitar, with its many doubled Bs - and we end up adding a number of them.

When I return home to review all of the changes, I start to see the potential of the unison for clarifying the different threads in the texture: perhaps in $\mathrm{m}$. 11, we can do even better (figure 11d). Because it is more of a color than a revision, I would suggest that anyone playing Beyond the White Hand experiment with added unisons, whether they are written or not. In fact, some of the additions that were approved that day are not in the published score. 
FIGURE 11 - Birtwistle, Beyond the White Hand, m. 9-11. (a) manuscript; (b) first suggestion by Julian Bream; (c) second suggestion by Julian Bream; (d) suggestion by the author.

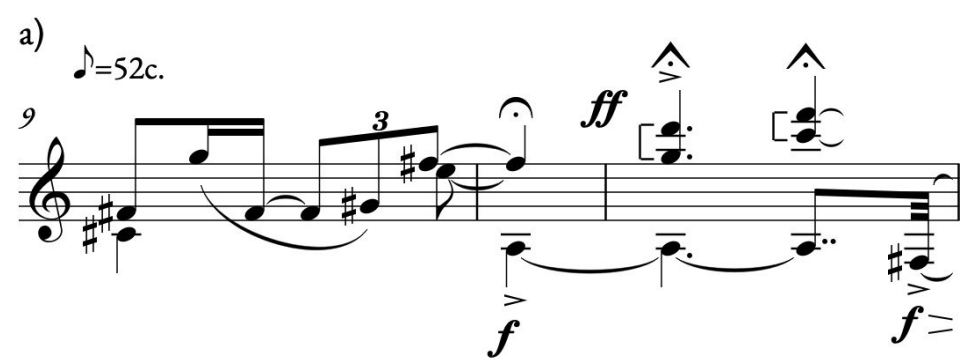

b)

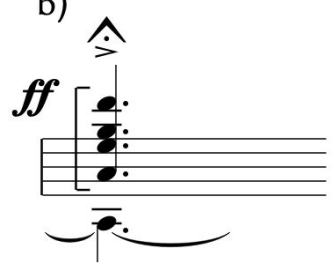

c)

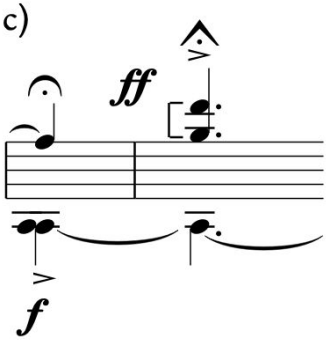

d)

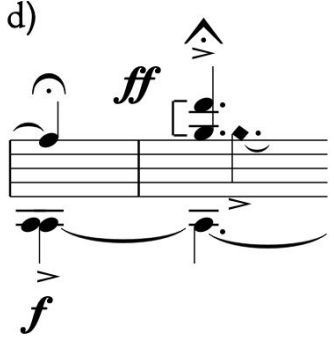

For close-spaced, aggressive sonorities, Birtwistle welcomes additions (figure 12). "Yes, that's a good, grungy sound," he says with satisfaction. Julian repeats the word "grungy" in an ironic, questioning tone: "That's a new one."

FIGURE 12 - Birtwistle, Beyond the White Hand, m. 55: additions in small noteheads by Julian Bream.

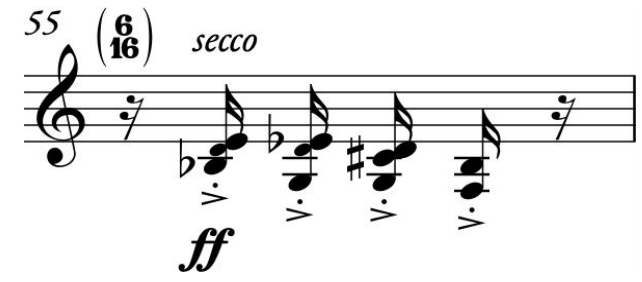


We arrive at the fast central section, which is frequently interrupted by references to the slower music - another color from Picasso's palette. Now Julian starts to suggest the effects that have stood him in good stead throughout his career: pizzicato, harmonics, tambura. At one point, Birtwistle has written a gesture, marked distanza, that repeats three times. Each repetition is more elaborate than the last-on the page, they look like three strange desert plants of the same species. The tapping gestures introduced earlier punctuate the gestures like the dots on Roman inscriptions (figure 13a).

"Jonathan, let's hear those chords with tambura. And harmonics the third time" (figure 13b).

FIGURE 13 - Birtwistle, Beyond the White Hand, mm. 70-74: (a) manuscript;

(b) tambura and harmonics suggested by Julian Bream.

a) Manuscript

$\lambda=63 \mathrm{c}$.

distanza

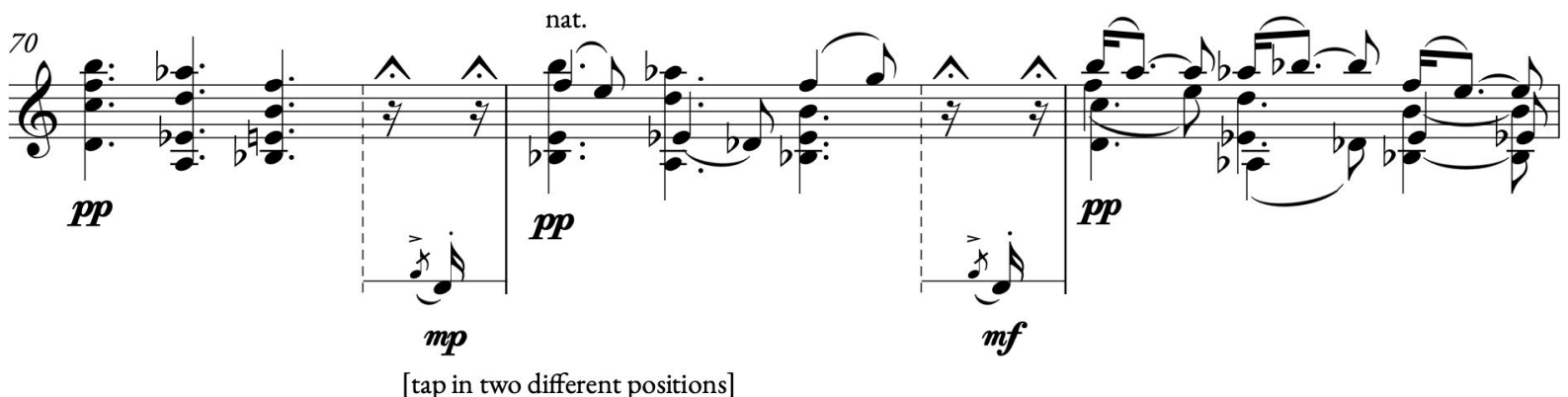

b) Tambura and harmonics suggested by Julian Bream

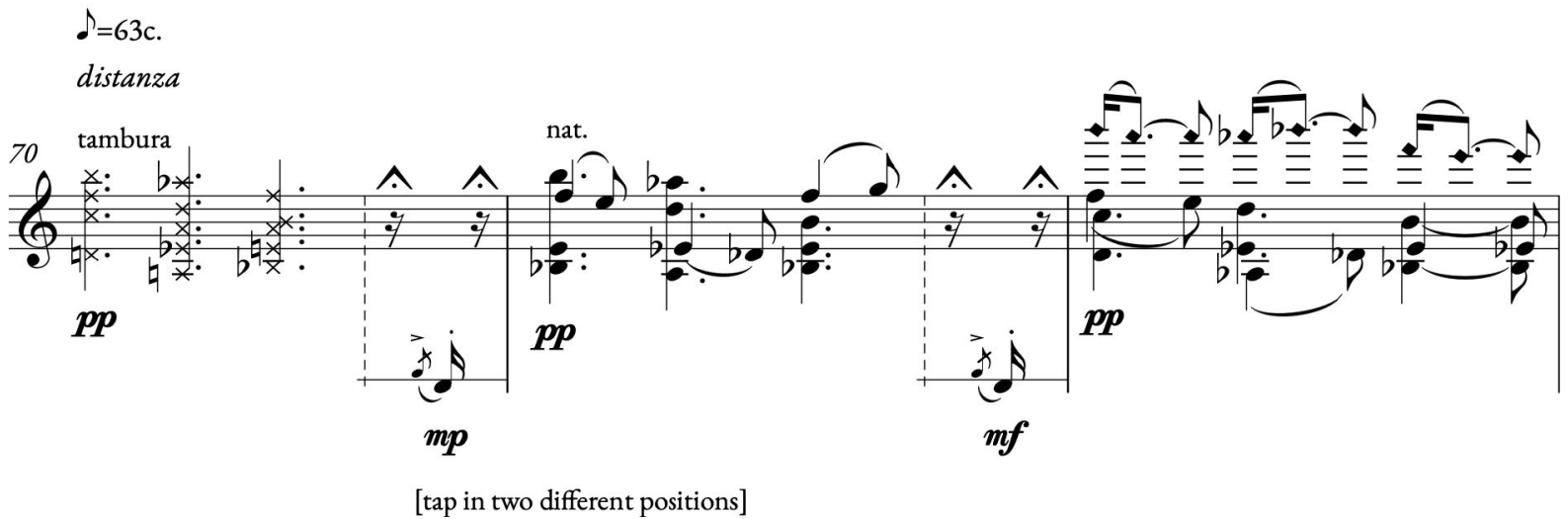

And now comes a moment of learning for me. Inwardly, I groan —of course Julian would want this effect, but for me, it's too much about the effect and too little about the harmonies. I've grown to love these combinations of perfect fourths, perfect fifths, and tritones. I think the chords should 
be soft, dark, but ruthlessly clear and precisely voiced. But Harry approves: "Beautiful," he says. I have misjudged the music here: there is after all a place for obscurity and veiled sonorities, and such sounds, too, can be integrated with the harmony of the piece.

Soon we arrive at a passage that only Birtwistle could write, another one of his "clocks" (figure 14). It's a hocket—-that is to say, a single line divided between two voices (for another example, see the chromatic melody in the opening measures). In this hocket, the two lines are set in contrasting registers and dynamics, high and low, soft and loud, but interlocking rhythmically. Each line describes an ostinato, but each repetition of the pattern is an imperfect copy of the last, with unpredictable note and rest lengths. That day, it's my favorite passage in all guitar music, but for it to succeed, the two lines must be absolutely distinct. In the earlier meeting I played it for Harry with the lower voice pizzicato and with the most aggressive attack I could produce. He liked it, but I want Julian to weigh in. He asks to hear it with the lower voice at the bridge and the upper voice near the soundhole. As often during this session, I feel stretched to my limit—one of the toughest guitar lessons I have taken.

FIGURE 14 - Birtwistle, Beyond the White Hand, mm. 140-43.

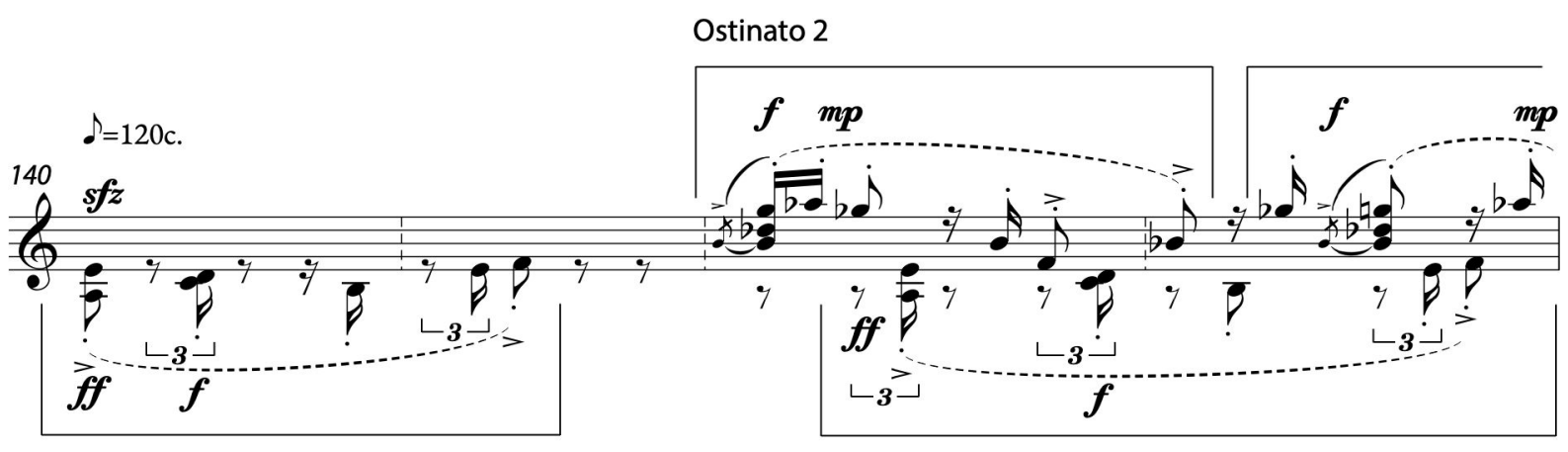

Ostinato 1

\section{VII}

A couple of weeks later, I'm back in Denver and something arrives in the post. A single sheet of manuscript containing the requested extension to the crazy high passagework, joined to the rest of the piece by another passage of clockwork. It looks almost impossible to play, but at the top Harry has written: "Dear Jonathan, Go for it, you can't kill it. Love, H."

What happened to the piece after I withdrew? Naturally, it went through more sessions with Julian and Harry, this time with Andrey Lebedev providing a new perspective with his own artistry and considerable experience with new music. The piece is now published by Boosey and Hawkes, 
edited by Julian. Check the published version, and you will see that many of the ideas in this narrative did not survive. This is easily explained: work with any great musician, and each meeting takes on its own life, even with the same people and the same music.

And yet I am left with the impression that in music as robust as this, players need not necessarily stick to traditional dividing lines between the performer's and the composer's domains. In the traditional scheme, a performer feels entitled to choose such things as which string to play a line on, how to apply slides and perhaps slurs, where to place the right hand to find the color, how to use the nails, and so on-while it is the composer who decides whether or not to apply pizzicato, harmonics, tambura, and other effects. I wonder if such a strict boundary should constantly obtain in music such as this, in which the character of each episode must immediately be made vividly clear in medias res. It is still the performer's task to "make it more like itself."

\section{VIII}

That July evening had a long way to go when the first bottle of burgundy was opened. It was one in the morning when Julian announced, "Now let's listen to the Berg Violin Concerto." There was a new recording out with Isabelle Faust as soloist and Claudio Abbado conducting the Berlin Philharmonic, and Julian had already enthused about it on the phone. As we reached the point in the third movement where Bach's chorale Es ist genug enters, I saw Julian listening quietly and intently. He was two weeks away from his eightieth birthday. I sat up a bit straighter.

Every meeting with Julian was a reminder to commit more deeply to the path of the interpretive musician. He was incapable of thinking of a passage of music without human context: from our first musical conversation (about Janáček’s Piano Sonata) to our last (about the Berg Concerto), he would speak about the place, the politics, and the biography of its creator. What used to astonish me was how instinctively he would construe an entire culture around a passage of music and how articulate he was in voicing it. As I listened to his commentaries, I would feel a prick of conscience, and a vision of simplicity would open up before me: if I could make these connections as easily as Julian Bream, all interpretive decisions would follow as a matter of course.

That is a small part of what I learned from him. 


\section{ACKNOWLEDGMENTS}

I would like to thank Selma Antunes for permission to reproduce her Releitura, and Christopher Freitag, Diogo Alvarez, and Robert Ferguson for their helpful suggestions.

\section{REFERENCES}

BIRTWISTLE, Harrison. Beyond the White Hand: Construction with Guitar Player (2013). Edited by Julian Bream. London: Boosey \& Hawkes, 2019. Score, 24 pages. Guitar.

-_- Guitar and White Hand (2007). Performed by Forbes Henderson, guitar. August 17, 2011. Online: <https://youtu.be/HvyfJvwYUmQ>. Accessed December 28, 2020.

GERHARD, Robert. Fantasia (1957). London: Mills Music, 1964. Score, 3 pages. Guitar. GOLLANCZ, Victor. Man and God: Passages Chosen and Arranged to Express a Mood about God and Man. Boston: Houghton Mifflin, 1951.

PALMER, Tony. Julian Bream: A Life on the Road. London and Sydney: Macdonald, 1982.

UMLAND, Anne. Picasso: Guitars 1912-1914. New York: Museum of Modern Art. 2011.

\section{ABOUT THE AUTHOR}

Jonathan Leathwood teaches guitar, music analysis, and the Alexander Technique at the University of Denver's Lamont School of Music, where he is Chair of Guitar. He gained his $\mathrm{PhD}$ at the University of Surrey and his B.Mus at King's College London. As a recitalist, he has appeared at Wigmore Hall (sponsored by the Julian Bream Trust), the Leo Brouwer Festival in Brazil, the Cheltenham Festival, and many other venues in Europe and on both American continents. His recordings of Goss, Dodgson, Malloy, and Keeley are available on the Cadenza and NMC labels. ORCID: https://orcid.org/0000-0003-3419-4934. E-mail: Jonathan.Leathwood@du.edu 